\title{
CONTEMPORARY PERSPECTIVES ON IMPROVING EFFECTIVE TEACHING AT FIRST YEAR STUDENTS IN ENGINEERING HIGHER EDUCATION- A STUDENTS' PERSPECTIVE
}

\author{
Lorena Peculea, Ph.D., \\ Adrian PECULEA, Ph.D. \\ Technical University of Cluj-Napoca, Romania \\ lorena.peculea@dppd.utcluj.ro
}

Abstract: The ultimate criterion of effective teaching is effective and successful learning. The paper focuses on an ascertaining research that investigates the students' opinion about the effective teaching characteristics through a survey based on a questionnaire that was sent to 233 first year students from Technical University of ClujNapoca, Romania, attending classes to prepare for a teaching career. The revised set of characteristics of effective teaching according to the Griffith University's PRO-Teaching project (Klopper, C., Drew, S., 2015) presented originally as 'eight dimensions of good teaching' (Nulty, 2001) provided a structured framework that has been the basis for our study in students' evaluation of effective teaching. The data collection procedure was based on a survey with a 5-point Likert scale and an open-ended question with comment box. The students in the contemporary educational system prefer interactive teaching strategies, suitable personal characteristics of teachers and a good teacher-student relationship.

Keywords: effective teaching; learning; metacognition; higher education; future teachers.

\section{Focus of the paper}

The emergence of the discourse around teaching and learning is one of the more remarkable phenomena of the last decade in higher education. There is a substantial research evidence that shows how good teaching makes a 
difference in student learning, so that students who are well taught learn more than students who are poorly taught. Currently, teaching is increasingly perceived as putting the student in the formal learning situation as a development of student learning ability, making him more responsible and more involved in the act of learning. Thus, the ultimate outcome of instructional practice is effective student learning (Donald, 2000). Good teaching encourages high quality student learning (Ramsden, 1992). The ultimate criterion of effective teaching is effective and successful learning; new pedagogies should help students develop over time as independent, autonomous learners able to effectively design, pursue and achieve their own learning goals and personal aspirations as well as master curricular learning goals. The ultimate goal for teachers, as John Hattie has described, is to 'help students to become their own teachers' (2014). The premise of our study was to enhance teaching practice and student learning, in order to address the perceived need to improve teaching quality (teaching for learning) and to provide opportunities for future teachers to improve their understanding of effective teaching and of their learning (learning for teaching). The ten characteristics of effective teaching presented originally as 'eight dimensions of good teaching' (Nulty, 2001) provided a structured framework that has been the basis for students' evaluation of effective teaching in engineering higher education.

\section{Theoretical framework for the study}

\subsection{Defining effective teaching}

The importance of effective teaching is recognized throughout the literature. Tarr et al. (2006) asserts that at the heart of quality education is quality teaching. Teaching is not a single activity, but is comprised of content knowledge/expertise and a set of activities or skills necessary to facilitate and assess student learning.

Effective higher education teaching is a 'contested concept' (Skelton, 2004) with varying definitions. Numerous attempts have been made to identify its characteristics, using a variety of theoretical perspectives, but there is no universally accepted definition of effective university teaching (Johnson \& Ryan, 2000; Paulsen, 2002; Trigwell, 2001). There is an abundance of lists offered throughout the literature of what constitutes effective teaching (Sullivan, 2001; Young, 2006; Childs, 2010; Buchanan, 1997; Nicholls, 2002; Reid \& Johnstone, 1999; etc.). These lists focus on a diverse range of practices such as lesson preparation and delivery, assessment and feedback and characteristics such as patience and professionalism. Although each list is undoubtedly effective in theory, 
research suggests that this does not transfer in practice. For instance, Centra (1993) defines effective teaching as 'that which produces beneficial and purposeful student learning by using the appropriate procedures'. Braskamp and Ory (1994) include both teaching and learning in their definition, defining effective teaching as the "creation of situations in which appropriate learning occurs; shaping those situations is what successful teachers have learned to do effectively'. Campbell, Kyriakides, Muijs and Robinson (2003) defined teacher's effectiveness as the impact of classroom factors on the performance of student, while P. Westwood (2006) believes that effective teaching is as an approach of providing all the students with utmost opportunities. McKeachie (1994) defined effective teaching as 'the degree to which one has facilitated student achievement of educational goals'. That means teaching is effective when it achieves its intended educational goals.

So, effective teaching has been broadly understood as teaching that is oriented to and focused on students and their learning, that is deep and meaningful. Defining teaching effectiveness can be approached from either an instructional process perspective or from an educational outcomes process perspective (d'Apollonia \& Abrami, 1997). Although both teacher characteristics and course grades can be considered as indicators of the effectiveness of teaching, they are influenced by external factors. Hence, other sources, such as the students' perceptions of their learning should be used to complement the data. Some researchers suggest, it is what the students can do or what they believe they can do, that should be considered as indicators of the effectiveness of teaching (Ramsden, 2003). 'Teaching gains a functional and effective structure in the context of other didactic activities if and only if it induces a real learning process, motivating students to engage in activities that require effort, understanding, assimilation of values (knowledge, skills, attitudes), to make transfers and creative applications' (Neacsu, I., 1990).

Higher education has utilized student evaluations of teaching effectiveness as a means of measuring the degree of teaching effectiveness that is present in the classroom (Algozzine et al., 2004; Hendry \& Dean, 2002; Steiner, Holley, Gerdes \& Campbell, 2006; Wright, 2006). Student evaluation of teaching effectiveness were initially intended as a mechanism for students to provide feedback that teachers could utilize to inform and guide change in instructional methods.

\subsection{Characteristics of effective teaching}

Effective teaching is complex and research indicates that measures of effective teaching are multifaceted and multidimensional (Marsh \& Roche, 1997; Sheehan \& DuPrey, 1999; Tang, 1997; Feldman, 2007; Biggs, 2003; Nulty, 2001; etc.). Although Patrick \& Smart (1998) claim that there appears 
to be little agreement on the nature and number of dimensions that represent teaching effectiveness, their view is not shared by most researchers in the field. Focusing on higher education, Ramsden (1992) comments, 'although good teaching is undoubtedly a complicated matter, there is a substantial measure of agreement among these empirical studies about its essential characteristics.' So, an extant of literature provides numerous accounts that describe characteristics of effective teaching.

Ralph (2003) conducted a study on teaching effectiveness using how well students learn as the criterion. The students were given 32 hypothetical instructor profiles and were asked to rank nine selected teaching factors developed by Marsh and Hocevar (1993). Ralph identified five attributes of effective instructors: commitment to learners; knowledge of material; organization and management of the environment; desire to improve; collaboration with others. Ralph concluded that 'exemplary teaching is identifiable and the quality of its constituent components can be assessed' (Delaney et al., 2010). More recently, in a study of graduate students enrolled in a course on curriculum design and teaching methods, Saroyan et al. (2009) found the students expressed four ideas about effective teachers' actions. Specifically, effective teachers convey knowledge, prepare and manage instruction, promote learning and help students grow so they can learn independently. After the course, the students were inclined to place more emphasis on the promotion of learning and student growth. In a study, Marsh (2010) delineates the characteristics of effective teachers to include 'highly knowledgeable, communicate well, give clear instructions in their teaching and have good relations with children, staff, and parents'.

The revised set of characteristics of effective teaching according to the Griffith University's PRO-Teaching project (Klopper, C., Drew, S., 2015) presented originally as 'eight dimensions of good teaching' (Nulty, 2001) provided a structured framework that has been the basis for our study in students' evaluation of effective teaching. Refining characteristics of effective teaching has principally involved moving the focus from the teacher to the effect of the teaching upon the students. Effective teaching connotes a suite of teacher behaviors that encompass not only what the teacher does, but also what the student does (Shuell, 1986) and thatis ultimately more important as Biggs (2003) has emphasized.

\section{Methodology}

\subsection{Research design}

To investigate the university students' opinion about the effective teaching characteristics measured on ten dimensions (Klopper, C., Drew, S., 2015), an exploratory study design was realized which aimed to identify the level of the development of these variables. For this purpose, answers to the 
following question were sought: What is the perception of first year students (future teachers) on the qualities of effective teaching? The data gathering procedure was the implementation of the questionnaire. The obtained data were statistically descriptive analyzed by calculating mean, standard deviation and frequency distribution. In the process of analysing and interpreting the data obtained, we used the SPSS 21.0 statistical software.

\subsection{Participants}

The participants in this study were first year students from Technical University of Cluj-Napoca, enrolled in the program for initial training of teachers for secondary education. Of the 233 students, 128 students were male and 105 were female students.All students were invited to take part in the study; no coercion was exercised and there were no penalties for nonparticipation.

\subsection{Measures}

The revised set of characteristics of effective teaching according to the Griffith University's PRO-Teaching project (Klopper, C., Drew, S., 2015) has been presented originally as 'eight dimensions of good teaching' (Nulty, 2001). It provided a structured framework that has been the basis for our study in students' evaluation of effective teaching. The dimensions of effective teaching were built on observable indicators of the behaviors manifested by the teachers. The quantitative research instrument was named the Student' Evaluation Questionnaire on Effective Teaching. The final version of the questionnaire included ten items, a five-point Likert scale which allowed respondents to express a very large extent (1), largely (2), a small extent (3), a very small extent (4) and not at all (5) in response to each of the statements included and an open-ended question with comment box. The Cronbach-alpha coefficient calculated for the final version indicates a very good internal consistency of the research tool $(\alpha$ Cronbach $=0.807)$.

\section{Results}

Concerning the perceived level of effective teaching for future teachers, it was resorted to calculating an average of the participants' responses for each of the ten dimensions of effective teaching. The data obtained are shown in Table 1. Analysis at the level of observed scores for each variable followed showed a medium perceived level of effective teaching. For effective teaching the highest scores were recorded at using appropriate teaching materials and aids and the lowest scores were recorded at regularly testing student knowledge, giving feedback.

Asked which is the general opinion in terms of defining and conveying clear, explicit, realistic and challenging yet the achievable aims and learning 
objectives, respondents had different opinions. Thus, if a share of $72.1 \%$ of them stated that the opinion is a very large extent and largely, a rate of $27.9 \%$ stated that their opinion is a small extent and a very small extent. It's important to note that there has been no response indicating the clear, explicit, realistic definition of aims and learning objectives.

Table 1. The perceived level of the effective teaching

\begin{tabular}{|c|c|c|c|c|c|}
\hline $\begin{array}{l}\text { Dimensions of the effective } \\
\text { teaching }\end{array}$ & $\mathbf{N}$ & Mean & $\begin{array}{l}\text { Std. } \\
\text { Deviatio } \\
\text { n }\end{array}$ & Lower & $\begin{array}{l}\text { Hi } \\
\text { gh } \\
\text { er }\end{array}$ \\
\hline $\begin{array}{l}\text { 1. Making clear the achievable } \\
\text { aims and learning objectives }\end{array}$ & $\begin{array}{l}23 \\
3\end{array}$ & 2.24 & 0.676 & 1 & 4 \\
\hline $\begin{array}{l}\text { 2. Demonstrating advanced } \\
\text { discipline knowledge }\end{array}$ & $\begin{array}{l}23 \\
3\end{array}$ & 2.09 & 0.821 & 1 & 5 \\
\hline $\begin{array}{l}\text { 3. Using pedagogical/teaching } \\
\text { techniques and strategies }\end{array}$ & $\begin{array}{l}23 \\
3\end{array}$ & 2.81 & 0.798 & 1 & 5 \\
\hline $\begin{array}{l}\text { 4. Demonstrating suitable } \\
\text { personal characteristics }\end{array}$ & $\begin{array}{l}23 \\
3\end{array}$ & 2.80 & 0.803 & 1 & 5 \\
\hline $\begin{array}{l}\text { 5. Regularly testing student } \\
\text { knowledge, giving feedback }\end{array}$ & $\begin{array}{l}23 \\
3\end{array}$ & 3.03 & 0.991 & 1 & 5 \\
\hline $\begin{array}{l}\text { 6. Encouraging to reflect on own } \\
\text { knowledge or on other new } \\
\text { areas of knowledge }\end{array}$ & $\begin{array}{l}23 \\
3\end{array}$ & 2.87 & 0.985 & 1 & 5 \\
\hline $\begin{array}{l}\text { 7. Organizing learning activities } \\
\text { in a structured and coherent } \\
\text { manner }\end{array}$ & $\begin{array}{l}23 \\
3\end{array}$ & 2.37 & 0.991 & 1 & 5 \\
\hline $\begin{array}{l}\text { 8. Using the available features of } \\
\text { the learning environment }\end{array}$ & $\begin{array}{l}23 \\
3\end{array}$ & 2.37 & 1.026 & 1 & 5 \\
\hline $\begin{array}{l}\text { 9. Using appropriate teaching } \\
\text { materials and aids }\end{array}$ & $\begin{array}{l}23 \\
3\end{array}$ & 1.89 & 0.769 & 1 & 5 \\
\hline $\begin{array}{l}\text { 10. Revealing a scholarly } \\
\text { approach to teaching and } \\
\text { seeking to improve teaching } \\
\text { performance }\end{array}$ & $\begin{array}{l}23 \\
3\end{array}$ & 2.47 & 0.866 & 1 & 5 \\
\hline Total & & 2.49 & & & \\
\hline
\end{tabular}

Figure 1. Distribution of the answers for the first dimension

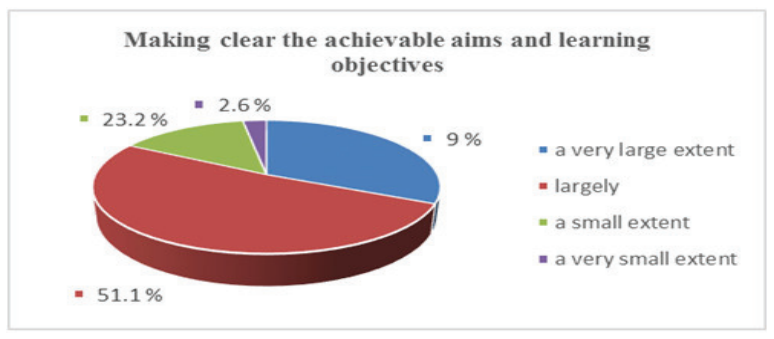


Thus, a significant percentage of students (52.4\% largely and $22.7 \%$ a very large extent) believe that the teachers demonstrate that they have advanced content knowledge by creating clear explanations and addressing student questions. A very low percentage of respondents $(18.9 \%$ in a small extent and $5.6 \%$ a very small extent) states that teachers demonstrate advanced content knowledge as shown in the data interpreted statistically.

Also, a percentage of $29.6 \%$ (largely) and $3.9 \%$ (a very large extent) of students believe that teachers demonstrate a teaching style supported by appropriate strategies for creating interest and effectively engaging students in learning activities. We notice a significant percentage (64.8\%) of students who believe that teachers exhibit in small extent and a very small extent a teaching style supported by appropriate strategies. The frequencies for each answer are shown in the figure below:

Figure 2. Distribution of the answers for the third dimension

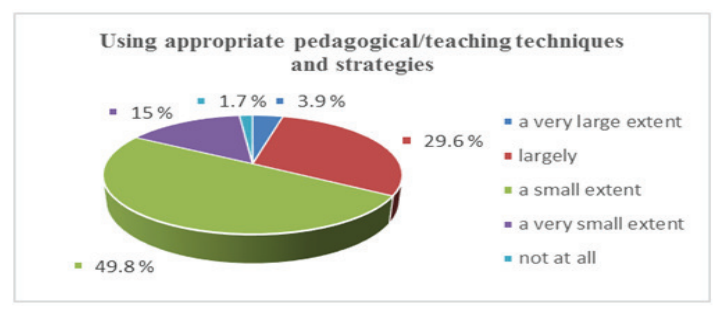

We also note that a large percentage of university students involved in observational research consider that the teachers exhibit personal characteristics that engage, stimulate, encourage and inspire students to learn in a large extent $(33.9 \%)$. From the answers of most students $(48.5 \%$ and $16.7 \%$ ) results that in a small extent and a very small extent teachers display concern for students and their learning, motivation, availability to students to render assistance.

There is a percentage of university students $(31.3 \%)$ who recognize that in a large and a very large extent the teachers engage with activities in class that test student understanding and then adapt or adopt teaching strategies to further develop that understanding. A significant percentage of respondents (35.6\% in a small extent and $26.6 \%$ a very small extent) state that teachers engage less with the use of formative assessment procedures. It's important to note that that there have been 15 responses indicating the teachers do not engage with activities that test student understanding (see figure below). 
Figure 3. Distribution of the answers for the fifth dimension

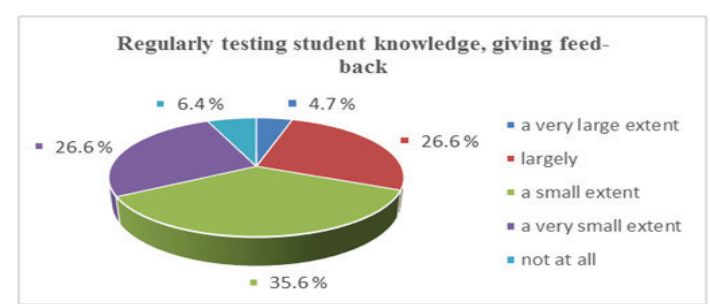

Following the opinion of university students regarding the frequency of behaviors by which teachers encourage students to reflect and share what they already know about the topic, discuss how it relates to others things that they know and hypothesize about its implications for particular problems and cases, the responses are as follows: $6.4 \%$ a very large extent, $31.3 \%$ largely, $36.5 \%$ a small extent, $20.6 \%$ a very small extent and $5.2 \%$ not at all.

We also note that a large percentage of university students involved in our research consider that the teachers organize learning activities and assessments in a structured and coherent manner that assists students to achieve the stated learning objectives in a large and very large extent $(60.1 \%)$.

Figure 4. Distribution of the answers for the seventh dimension

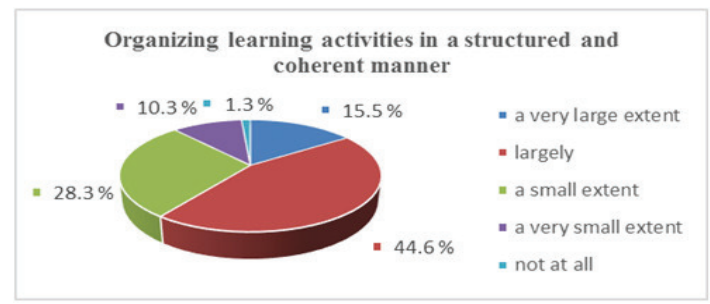

The results are shown in the figure above. A low percentage of respondents (28.3\% in a small extent and $10.3 \%$ a very small extent) states that teachers organize learning activities and assessments in a structured and coherent manner.

Aiming at following university students' opinion regarding the frequency with which teachers effective use the available features of the learning environment (temperature, lighting levels, noise levels etc.) to enhance their teaching and the student learning experience, from the analyzed data it appears that much of the students $(60.9 \%)$ state that teachers use the available features of the learning environment. 
To the question 9, 'To what extent the teachers choose appropriate teaching materials and aids and make use of them in an appropriate manner that assist students to reach the learning objectives?', most students surveyed rated their teachers use appropriate teaching materials and aids in a very large extent $31.8 \%$, respectively largely $51.1 \%$. Less than a quarter of the subjects, 39 subjects, rated as a small extent the teachers use appropriate teaching materials and aids (see figure below).

Figure 5. Distribution of the answers for the ninth dimension

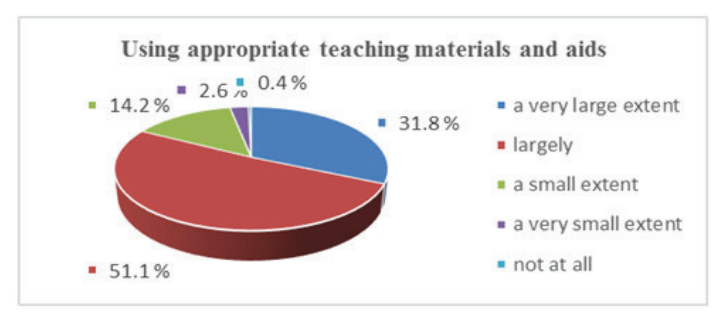

Thus, the most students $(54.5 \%)$ responded that their teachers demonstrate a commitment of improving their teaching. We notice a percentage of $36.1 \%$ in small extent and $6.9 \%$ a very small extent of students' responses who believe that teachers demonstrate a scholarly approach to teaching and seek to improve performance.

\section{Discussions}

The paramount aim of teaching is that students learn. Effective teaching is roughly defined as teaching that brings about effective and meaningful student learning. Successful student learning is achieved through a continuous process of students' linking new knowledge to their experiences and their existing knowledge base. Good teaching is that which helps students take control of their learning. This happens best 'when teachers see learning through the eyes of their student and students see themselves as their own teachers' (Hattie, 2014). The teacher is not only a subject of education what assumes different roles of teaching activity, but also an active person of their own training in order to be able to carry out an efficient and beneficial activity both from the viewpoint development of the personality the beneficiaries of education and as training and continuing development.

The major objective of this study was to identify the perception on the qualities of effective teaching at future teachers. The analysis of participants' responses, as presented in Table 1, shows that future teachers' qualities of effective teaching is generally positive. On Likert scale with 5 points, used for research, it appears that the favorable/ positive qualities of effective teaching of future teachers has an average $M=2.49$. Across all the 
questions examined in this study, the scores awarded by respondents indicate a more favorable perspective than unfavorable on effective teaching characteristics. The students surveyed appreciate that they are generally satisfied about what they have been offered and their dissatisfaction relates to more subtle aspects of teaching such as teaching strategies, studentteacher relationships, personal characteristics of teachers in this context, as shown in open response question. Also, an important place is the explanation and implementation of the information, as well as the deepening the contents of the courses.

According to a large percentage of university students the clarity of aims and objectives is useful because it means that the act of teaching can be purposeful, deliberate and planned. Framing any instructional act by stating its aims and learning objectives is the first opportunity to engage students, providing clear purpose, relevance and a focus for their learning efforts. Well-organized courses consider learning objectives as an essential component of each course's design. Clearly formulating and setting the operational objectives (in terms of observable behavior) and communicating them to the students, who will accept them and then internalize and assume them are a fundamental component of effective teaching.

From the perspective of most students, the effective university teachers demonstrate excellent knowledge of their subject and this is a necessary attribute of an effective teacher. These perceptions align strongly with the importance of creating a supportive learning environment and scaffolding learning, of organizing learning activities in a structured and coherent manner, of encouraging to reflect on own knowledge or on other new areas of knowledge and notably with Biggs' (2003) work on constructive alignment. The discipline content knowledge and the pedagogical skills are inextricably linked. Effective teachers focus on learning and learning outcomes by having a strong understanding of the content and pedagogical content knowledge. Rather than focusing on what teachers need to teach and how they should teach it, teachers need to subtly shift their paradigm to what it is that students need to learn and how they will best learn it (Biggs \& Tang, 2007). The teachers select and structure the content adequately, ensuring their articulation and adaptation according to the specifics of the group of students (general level of training, interest, motivation, etc.). It seems that teachers who teach based on the exposure of the content, set for themselves very well the information they want to teach and can successfully deal with the questions of the students about the contents they have spoken, so they know very well the scientific information they have to teach, but does not attach great importance to explaining the practical relevance of content. 
From the student's point of view, only $33.5 \%$ of students consider that their teachers demonstrate a teaching style supported by appropriate strategies for creating interest and effectively engaging students in learning activities. The university teachers can use a myriad of strategies to optimize student learning. Cooperative learning groups (group projects) give students opportunities to collaborate on brainstorming ideas and completing the learning tasks. Teachers can enable students to think critically and to solve problems by integrating problem-based assignments for students to complete individually or in a group. Problem based learning stimulates students to develop the ability to think critically, analyze problems, find and apply appropriate learning resources. The experiential learning activities allow students to apply knowledge, encourage collaborative participation and engagement and stimulate students' communication, social and problem solving skills. Personalized reflection and applying learning to other contexts are critical factors in effective experiential learning. Case studies are another interactive method with a positive impact on learning, develop the capacity to analyze practical situations, critical thinking, decision making, research capacity, cooperative work. Teachers can also develop hybrid courses that integrate online components into traditional classroom settings, allowing student to interact with the teacher and other students and complete group activities in class or assignments and submit them by e-mail, Google Drive, Blackboard or other venues. Teachers' use of various methods and strategies in the presentation of subject content, in important discussions and debates and in encouraging small group interactions may help to nurture student curiosity. These approaches encourage students to study issues from divergent views. The activation should be understood not only as a means of optimizing the instructive-educational actions, but also as an opportunity for the induction and orientation of the individual study and the autonomous study of the student. In other words, the student carries the means of his own development. Therefore, from the point of view of the interviewed students, teachers relying on deepening practical aspects are convinced that providing examples and practical experiences to students have a greater influence on the learning process, so it is preferable to a classical teaching method. According to the interviewed students, teachers are not only concerned with the simple transmission of knowledge, but also with the means of transmitting them, which involves accessing the subject matter and supporting the students in acquiring them, both cognitively and metacognitively.

Future teachers have preferences for specific characteristics of effective teacher because some of them lead to results that students desire. Demonstrating suitable personal characteristics (patient, flexible, good listener, empathetic, enthusiastic etc.) is only one factor of a good teaching. 
The participants of the study put emphasis that a teacher should be innovative, motivating, dedicated, active, knowledgeable and interactive, as shown by data from open response question. Our results coincide with Santrock's (2010) that in effective teaching, a teacher should have both professional knowledge/expertise and personal characteristics like, dedication, motivation and caring attitude towards work and students.

The data on regularly testing student knowledge, giving feedback (35.6\% in a small extent and $26.6 \%$ a very small extent) shows the low use of formative assessment practices, poor representation of assessment activities that can respond to the particular needs of students immediately. This leads to the impossibility of regulating the educational action along the way, which consequently has negative effects on the level of performance of the students requiring differentiated or intensive care and support. The university teachers should learn from their students by continuously assessing the effect of their teaching on student learning and modifying their approach based on that evidence. Consequently, formative feedback serves to inform both the teacher and the student and is, at the same time, critical to both the teacher's and the learner's effectiveness. The critical evaluation of learning outcomes has the potential to indicate new teaching strategies. The application of formative assessment practices as a way of developing teaching styles to student learning needs is an important aspect covered in the literature. Evaluation valued as an authentic training tool, which allows to regulate the training by the student himself, to construct their own routes, becomes a self-regulated evaluation, a highly personalized formative assessment (Bocoș, M., 2013). Among the assessment methods applicable to disciplines in the field of engineering sciences, the teachers include short exercises, homework or portfolios, as well as self-evaluation of assimilated knowledge and formed skills.

Achieving higher order learning outcomes occurs as the result of adopting a deep approach to learning and this is part of the role of an effective teacher. Accordingly, effective teaching focuses on encouraging deep learning outcomes and is characterized by the constructivist structuring of lessons, setting of learning tasks, creation of challenge and provision of quality feedback that leads to students' engagement with personal reflective questions. An imperative for the design of didactic activities is the need to develop both a disciplinary reflection on the scientific content to be approached and a transversal pedagogical reflection on the act of learning. The optimal ways of articulating the factors that influence it are: students' intelligence profiles, learning styles, learning and teaching strategies valorized, didactic methodologies etc. The reflective-interactive training model values the individual and collective personal reflection of students about new cognitive and metacognitive knowledge and strategies, but also 
the debate over various issues, direct experimentation on objects, phenomena and processes of reality, as a preparation for integration into society. Students should be learnt how to learn the different subjects of study and there should be explicit concerns for the development of their metacognitive abilities. To further stimulate students, teachers can include in activities the learning strategies that empower them to enhance metacognitive abilities by applying classroom information to their own lives. Through using learning strategies and stating course expectations and goals, teachers help students increase their self-regulation skills and take responsibility for their learning. Encouraging students to take ownership of their learning also allows them to experience enhanced self-direction and self-awareness.

An elaboration on the expression of seven dimension emphasizes the elements of structure and coherence that generate a sense of organization to the teaching and learning activities in a class. A large percentage of university students consider that the teachers organize learning activities and assessments in a structured and coherent manner that assists students to achieve the stated learning objectives in a large and very large extent $(60.1 \%)$. It is essential for educators to provide detailed syllabi with course information, competences, objectives, assignments, course policies, due dates and a schedule. Teacher preparation, knowledge of subject matter and organization play an instrumental role in student success (Bain, 2004). The more organized and planning-oriented a teacher is, the more likely students will be to view him or her as knowledgeable and learn the material in a structured manner. The university curriculum as an ensemble of educational processes and learning, training and research experiences that the student makes during university studies, must be conceived as theory and practice that express the indissoluble unity between four fundamental elements: educational goals, educational content, instructional strategies and evaluation strategies.

Making appropriate use of the learning environment denotes the teacher's understanding of the limitations that the environment places on the effectiveness of different teaching strategies. To be most effective, the teacher must understand how to make optimal use of the range of tools and affordances available in that environment to complement teaching strategies and to enhance student learning. From our study, much of the students $(60.9 \%)$ state that teachers use the available features of the learning environment to enhance their teaching and the student learning experience.

With appropriate teaching materials and aids the intent is to improve the quality of explanation and stimulate student interest in teaching and learning activities, as seen in the high proportion of students' responses. In this matter, teaching materials and aids offer some facilitation as they offer multiple channels of information for learners with a range of learning 
approaches and styles. Design and preparation of the teaching materials is part of designing the activity that uses them appropriately. In this technologically driven society, integrating technology into classroom learning is essential. Using technology enables students to see tutorials online, access course information, submit assignments etc. Solely utilizing a didactic approach prevents students from optimally processing and applying their knowledge and has a negative impact on their ability to conceptualize material and practice skills. University teachers who integrate technology into their classrooms increase student engagement. Appropriate teaching materials and aids include online tutorials, instructional software and other web-based resources that enhance student engagement in place of standard presentation formats. Students practice skills through interactive tutorials and exercises, electronic presentations and demonstrations, reading materials developed by teachers, examples and exercises in the student's field of interest, links to other relevant online materials and individual and group laboratory assignments.

A scholarly approach to teaching is about being a reflective practitioner (Schön, 1983) and about engaging with scholarly literature to inform teaching practice (Shulman, 1986). It is time for teachers to rigorously analyze their own way of thinking and teaching, their own curricular reflection, to realize their advantages and disadvantages, to teach the students effectively metaknowledge and to form and develop metacognitive skills. Only by helping students to learn and only by trying to know and understand how they learn, their learning styles, learning strategies etc., teachers will be able to identify and implement flexible, more effective teaching methods to stimulate motivated cognitive and metacognitive learning.

\section{Conclusions}

Students have a pivotal role in making effective teaching. We consider relevant the fact that both for educational course activities and for laboratory, seminar and project activities, the expectations of the investigated students converge towards the processing and accessibility of contents, for their illustration and, especially, for highlighting their practical and applicative dimension.

Analyzing these teaching elements, we can assert that in the teaching from the perspective of conducting learning, students are actively involved in understanding and knowledge, taking into account the premise that the mere presentation of a content does not mean anything to a student unless it is suggested/recommended/indicated concrete ways of cognitive and metacognitive reporting to that content. Synthesizing, we can conclude that efficient teaching involves capturing the analytical attention of students, 
orienting their intellectual and practical action in well-defined directions, effectively changeling their effort to knowledge directed to solving learning tasks, imposing a learning rhythm and stimulating individual study efforts. Although the empirical base of this study is relatively small, we consider the findings can reveal some perspectives of the higher education system impact on students and can identify some landmarks of how an effective policy would come to be designed and implemented. Extending such study to other contexts of the instructional process and including larger samples would make it possible to form research-based studies that could inform teachers of initial training program, university teachers, higher education institutional managers and policy-makers about the effective teaching and quality of instructional process in Romanian higher education system.

\section{References}

Algozzine, B., Beattie, J., Bray, M., Flowers, C., Gretes, J., Howley, L., et al. (2004). Student Evaluation Of College Teaching. College Teaching, 52(4), 134-141.

Bain, K. (2004). What the best college teachers do. Cambridge, MA. Harvard University Press.

Biggs, J. (2003). Teaching for quality learning at university: What the student does (2nd ed.). Buckingham, England \& Philadelphia, PA: Society for Research into Higher Education: Open University Press.

Biggs, J \& Tang, C. (2007). Teaching for quality learning at university. Maidenhead: Open University Press/McGraw-Hill

Bocoș, M.-D. (2013). Instruirea interactivă. Repere axiologice și metodologice. Editura Polirom, Iași.

Braskamp L.A., Ory, J.C. (1994). Assessing faculty work: Enhancing individual and instructional performance. San Francisco, Jossey-Bass, CA.

Buchanan, P. (1997). Inspiring teaching. (J. Roth, Ed.) Bolton, MA: Anker Publishing Company, Inc.

Campbell, R. J., Kyriakides, L., Muijs, R. D., \& Robinson, W. (2003). Differentiated teacher effectiveness: Towards a model for research and teacher appraisal. Oxford Review of Education, 29, 347-362.

Centra, J.A. (1993). Reflective faculty evaluation. San Francisco, JosseyBass, CA.

Childs, P.E. (2010). Principles of Effective Teaching. Research and Resource Guide. National Centre for Excellence in Mathematics and Science Teaching and Learning, 1(14), 3-9.

d'Apollonia, S., \& Abrami, P. (1997). Navigating Student Ratings of Instruction. American Psychologist (November), 1198-1208. 
Delaney, J.G., Johnson, A. N., Johnson, T. D., \& Treslan, D. L. (2010). Students perception of effective teaching in higher education. St. John's, NL: Distance Education and Learning Technologies.

Donald, 1. G. (2000). Indicators 0/ success: From concepts to classrooms. Paper presented at the annual conference of the American Educational Research Association, New Orleans.

Feldman, K. A. (2007). Identifying exemplary teachers and teaching: Evidence from student ratings. In R. P. Perry \& J. C. Smart (Eds.), The scholarship of teaching and learning in higher education: An evidencebased perspective (pp. 93-143). Berlin, Heidelberg: Springer.

Hattie, J. (2014). Învăţarea vizibilă: ghid pentru profesori. Editura Trei, București.

Hendry, G. D., \& Dean, S. J. (2002). Accountability, evaluation of teaching and expertise in higher education. International Journal for Academic Development, 7(1), 75-82.

Johnson, T.D., \& Ryan, K.E. (2000). A comprehensive approach to the evaluation of college teaching. In K.E. Ryan (Ed.), New directions for teaching and learning: Evaluating teaching in higher education: A vision for the future (Vol. 83, pp. 109-123). San Fransisco, CA: Jossey-Bass.

Klopper, C., Drew, S. (2015). Teaching for Learning and Learning for Teaching. Peer Review of Teaching in Higher Education, Sense Publishers, Rotterdam.

Marsh, H. W., \& Roche, L. A. (1997). Making Students' Evaluations of Teaching Effectiveness Effective: The Critical Issues of Validity, Bias, and Utility. American Psychologist 52 (11), 1187-1197.

Marsh, C.J. (2010). Becoming a Teacher: Knowledge, Skills and Issues, 5th Ed., Frenchs Forest, Pearson Education.

McKeachie, W. J. (1994). Teaching tips: A guide book for the beginning college teacher. (9th ed.). Lexington, Massachusetts: D. C. Heath and Company.

Neacșu, I. (1990). Instruire și învățare. Editura Științifică, București.

Nicholls, G. (2002). Developing teaching and learning in higher education. New York: Routledge Falmer.

Nulty, D. (2001). Evaluation of educational programs: Issues for an effective policy framework. Paper presented at the Teaching Evaluation ForumStudent Feedback on Teaching: Reflections and Projections. Perth, Australia.

Patrick, J., \& Smart, R. (1998). An empirical evaluation of teacher effectiveness: The emergence of three critical factors. Assessment \& Evaluation in Higher Education, 23(2), 165-178.

Ramsden, P. (1992). Learning to teach in higher education. London: Routledge. 
Ramsden, P. (2003). Learning to teach in higher education (2nd ed.). London. Routledge and Falmer.

Reid, D.J., \& Johnstone, M. (1999). Improving teaching in higher education: Student and teacher perspectives. Educational Studies, 269-281.

Santrock, J. (2010). Educational psychology (5th ed.). McGraw-Hill.

Saroyan, A., Dangenais, J., \& Zhou, Y. (2009). Graduate students' conceptions of university teaching and learning: Formation for change. Instructional Science: An International Journal of the Learning Sciences, 37, 579-600.

Sheehan, E. P. \& DuPrey, T. (1999). Student evaluations of university teaching. Journal of Instructional Psychology, 26(3), 188-193.

Skelton, A. (2004). Understanding 'teaching excellence' in higher education: A critical evaluation of the National Teaching Fellowships Scheme. Studies in Higher Education, 29(4) 451-468.

Steiner, S., Holley, L. C., Gerdes, K., \& Campbell, H. E. (2006). Evaluating Teaching: Listening to Students While Acknowledging Bias. Journal of Social Work Education, 42(2), 355-376.

Sullivan, C. (2001). Rewarding excellence: Teacher evaluation and compensation. Alexandria, VA: National School Boards Association.

Tarr, J.E., Reys, J., Barker, D.D., \& Billstein, R. (2006). Selecting High Quality Mathematics Textbooks. Mathematics Teaching in the Middle School, 12(1), 50-54.

Trigwell, K. (2001). Judging university teaching. International Journal for Academic Development, 6(1), 65-73.

Young, S. (2006). Students views of effective online teaching in higher education. The American Journal of Distance Education, 20(2), 65-77.

Westwood, P. S. (2006). Teaching and learning difficulties: Cross-curricular perspectives. Camberwell, VIC: Australian Council for Educational Research.

Wright, R. (2006). Student Evaluations of Faculty: Concerns Raised in the Literature and Possbile Solutions. College Student Journal, 40(2), 417-422. 